\title{
Hydrogeomorphic effects on bedload scour in bull char (Salvelinus confluentus) spawning habitat, western Washington, USA
}

\author{
Jeffrey G. Shellberg, Susan M. Bolton, and David R. Montgomery
}

\begin{abstract}
We investigated the vulnerability of fall-spawned bull char (Salvelinus confluentus) embryos to redd scour during winter rain and rain-on-snow flood discharges in western Washington, USA. It was hypothesized that the magnitude of bedload scour at bull char redds is reduced by the provision and selection of stable refugia habitat controlled by local-, reach-, or subcatchment-scale variables such as hydraulic habitat unit and channel type. Bedload scour and channel change were measured using 96 scour monitors and 34 elevational transects in three catchments over 2 to 4 years. Scour to cited egg burial depths of bull char did not commence until discharge typically exceeded the 2-year recurrence interval. At a local scale, scour varied significantly among side channel, protected main channel, and unprotected main channel redd sites. Unprotected gravel patches in simplified channel types with moderate gradients were most susceptible to deep scour, especially if coupled with the transient supply and storage of sand and gravel from mass wasting. Partially transport-limited reaches had reduced scour due to lower stream power and armored gravel beds. Complex spawning habitat (i.e., with abundant large woody debris and side channels) was important in providing refuge from deep scour and in buffering embryos against inhospitable hydrologic or sediment regimes.
\end{abstract}

\begin{abstract}
Résumé : Nous examinons la vulnérabilité des embryons d'ombles à tête plate (Salvelinus confluentus) produits en automne à l'affouillement des frayères durant les débits de crue d'hiver dus à la pluie ou la pluie sur la neige dans l'ouest de l'état de Washington, É.-U. Nous avons émis l'hypothèse selon laquelle l'ampleur de l'affouillement causé par les alluvions de fond sur les frayères des ombles à tête plate est réduite par l'établissement et la sélection d'habitats de refuge stables contrôlés par des variables à l'échelle du site, de la section et du sous-bassin, tels que l'unité d'habitat hydraulique et le type de chenal. Nous avons mesuré l'affouillement causé par les alluvions de fond, ainsi que les modifications du chenal, à l'aide de 96 moniteurs d'affouillement et de 34 transects des relevés des élévations dans trois bassins versants pendant 2 à 4 ans. L'affouillement aux profondeurs connues d'enfouissement des œufs d'ombles à tête plate ne se produit pas ordinairement aux débits inférieurs à ceux de l'intervalle de récurrence de 2 années. À l'échelle locale, l'affouillement varie significativement selon qu'il s'agit de frayères situées sur un chenal latéral, sur un chenal principal protégé ou sur un chenal principal exposé. Les bancs de gravier exposés dans des chenaux de type simplifié avec des gradients modérés sont les plus vulnérables à un affouillement profond, particulièrement s'il existe concurremment un apport et une rétention transitoires de sable et de gravier provenant de mouvements en masse. Les sections à transport partiellement limité ont un affouillement réduit à cause de la puissance diminuée du cours d'eau et des bancs de gravier blindés. Les habitats de fraie complexes (c'est-à-dire avec de nombreux débris ligneux et des chenaux latéraux) sont importants car ils fournissent un refuge contre l'affouillement profond et ils protègent les embryons des régimes hydrologiques ou sédimentaires inhospitaliers.
\end{abstract}

[Traduit par la Rédaction]

\section{Introduction}

Salmonids have adapted to the natural discharge regimes of fluvial ecosystems (Lytle and Poff 2004). However, em- bryos of many salmonid species are present in the streambed before and during flood events that transport bedload, e.g., with fall-spawned embryos and winter floods or springspawned embryos and early summer floods. Streambed

Received 14 March 2009. Accepted 29 December 2009. Published on the NRC Research Press Web site at cjfas.nrc.ca on 10 March 2010.

J21104

Paper handled by Associate Editor Jordan Rosenfeld.

J.G. Shellberg 1,2 and S.M. Bolton. University of Washington, School of Forest Resources, Forest Hydrology, Box 352100, Seattle, WA 98195, USA.

D.R. Montgomery. University of Washington, Department of Earth and Space Sciences and Quaternary Research Center, Box 351310, Seattle, WA 98195, USA.

${ }^{1}$ Corresponding author (e-mail: j.shellberg@griffith.edu.au).

${ }^{2}$ Present address: Australian Rivers Institute, Griffith University, 170 Kessels Road, Nathan, Queensland 4111, Australia. 
scour (lowering of the streambed elevation) and fill during bedload transport can result in high mortality of incubating salmonids (e.g., Seegrist and Gard 1972; Erman et al. 1988).

The effects of scour on salmonid distribution and abundance at local to regional scales depends on fish size, life history strategy (i.e., iteroparity vs. semelparity), spawn time, amount of spawning and rearing habitat, local hydraulics, geomorphic reach type, sediment supply, discharge regime, and disturbance history. Montgomery et al. (1999) hypothesized that salmonids will not be able to persist in channel reaches with predictable deep scour during the incubation period ("bed scour hypothesis") unless fish locally bury their eggs below typical scour depths or spawn in sites with locally reduced scour. In low-gradient pool-riffle gravel-bed streams, large-bodied salmon avoid streambed scour by burying their eggs below typical scour depths during bankfull discharge (Montgomery et al. 1996). Bedload disturbance depths in low-gradient gravel-bed streams are on average less than two times the 90th percentile surface particle size $\left(2 \cdot D_{90}\right)$ (DeVries 2002).

In coarse mountain channels where the supply of spawning gravel is limited and transport capacity is high, smallerbodied salmonids with shallow to moderate egg burial depths may not be able to bury their eggs deep enough to avoid scour disturbance (i.e., below $2 \cdot D_{90}$ ). In addition, bedload transport and scour processes in channels where smaller-bodied salmonids typically spawn may be different than those active in pool-riffle or plane-bed channels where larger salmon spawn (Montgomery et al. 1999). Alternatively, at the local scale, many aquatic species avoid disturbance by selecting habitats that provide refuge from disturbance, preventing species exclusion at higher spatial scales (reach, segment, or catchment; Sedell et al. 1990).

The specific biology and life history of a salmonid can affect their exposure to scouring floods. For example, migratory bull char (Salvelinus confluentus) in western Washington spawn in cold mountain streams during the fall (September to December), peaking in October (Johnson 1991). They are medium-sized (300-800 $\mathrm{mm}$ in length), iteroparous, and long-lived (7-12 years) (US Fish and Wildlife Service 1998). Egg burial depths for migratory females average 10-15 cm (DeVries 1997; Shellberg 2002), which is less than larger fall-spawning Pacific salmon $(15-25 \mathrm{~cm})$ (DeVries 1997). Egg and alevin gravel residence times are prolonged and temperature-dependent, with hatching after 90-145 days at 2-4 ${ }^{\circ} \mathrm{C}$ (McPhail and Murray 1979; Shepard et al. 1984) and up to 220 days until gravel emergence (Goetz 1989; Stutsman and Ogg 2002; Shellberg 2002). These biologic factors put bull char eggs and alevins at high mortality risk from scour during late-fall and earlywinter peak flood events. However, bull char iteroparity may spread the risk of offspring mortality over multiple years.

Numerous studies have measured the patterns and processes of scour and fill in the spawning habitat of salmonids (e.g., Rennie and Millar 2000; Schuett-Hames et al. 2000; DeVries 2002; and others). However, most of these studies investigated sediment transport and scour patterns in lowgradient, pool-riffle channel types typically used by largebodied salmon. Sediment transport in steeper mountain streams has been examined in detail (e.g., Bathurst et al. 1983; Gintz et al. 1996), but only a few studies have meas- ured scour and fill in gravel patches used by smaller salmonids in mountain channel types (Kondolf et al. 1991; Barta et al. 1994).

The aim of this study was to investigate the previously undocumented vulnerability of bull char embryos to scour and fill of spawning gravels during fall and winter floods in mountain drainage basins of western Washington State, USA. It was hypothesized that the magnitude of bedload scour at bull char redds is reduced by the presence and selection of stable habitat refugia controlled by local-, reach-, or subcatchment-scale hydrogeomorphic variables. For example, energy dissipation around large woody debris (LWD) structures may reduce the effective shear stress available for bed scour in spawning gravels upstream or downstream of LWD. This habitat refugia component of the bed scour hypothesis (Montgomery et al. 1999) has not been explicitly tested for bull char or most salmonids in general. Therefore, selected hydrogeomorphic variables (hydraulic habitat unit, channel type, discharge magnitude and frequency, sediment transport regime) influencing measured scour and fill depths in bull char spawning locations were analyzed in three contrasting catchments in western Washington.

\section{Materials and methods}

\section{Study reaches}

Three study catchments were chosen from known spawning populations of migratory bull char in western Washington, USA: the upper Cedar River, North Fork (NF) Skykomish River, and South Fork (SF) Skokomish River. All three catchments are located in high-relief mountainous terrain in the Cascade or Olympic mountains, with moderate to dense conifer forest cover but different geology and forest land use (Table 1). Within each of the three catchments, two adjacent primary spawning reaches were chosen for detailed analysis, providing six reaches in total with contrasting reach-scale (100-1000 m) channel types (Table 1; sensu Montgomery and Buffington 1997).

The pool-riffle reaches of the upper Cedar River (including the Rex River) in the western Cascade Mountains are low-gradient channels with gravel beds armoured in patches and well-connected floodplains (Table 1). Obstructions such as LWD are rare, which is at least partially a result of historic riparian timber harvest. The varying yet abundant supply of gravel-sized particles and local gravel armouring lead to the presumption that gravel-sized bedload is at least partially transport-limited as compared with the available stream power (sensu Bravo-Espinosa et al. 2003). Char spawning typically occurs on straight riffles, riffle crests, or occasionally, side channels without other competing fall-spawning species. These reaches are located near the seasonal inundation zone of the large regulated Chester Morse Lake; however, backwater did not affect the stage, discharge, or water surface slope during the measured winter flood events in the study period.

The forced pool-riffle reaches of the NF Skykomish River below Goblin Creek in the western Cascade Mountains are moderate-gradient, cobble- and boulder-bed channels with numerous LWD, boulder, and bedrock obstructions. The associated floodplains are coarse-grained 
Table 1. Summary of physical conditions in different study catchments and reaches.

\begin{tabular}{|c|c|c|c|c|c|c|}
\hline & \multicolumn{2}{|l|}{ North Fork Skykomish } & \multicolumn{2}{|l|}{ South Fork Skokomish } & \multicolumn{2}{|l|}{ Upper Cedar } \\
\hline & Lower Goblin Creek & Below Goblin Creek & Above Church Creek & Below Church Creek & $\begin{array}{l}\text { Cedar River near } \\
\text { Camp } 18\end{array}$ & $\begin{array}{l}\text { Rex River near } \\
\text { Boulder Creek }\end{array}$ \\
\hline Channel type & Forced step-pool & Forced pool-riffle & Forced pool-riffle & Forced pool-riffle & Pool-riffle & Pool-riffle \\
\hline Gradient, \% & $1.5-3.5$ & $0.7-1.5$ & $0.8-1.5$ & $0.8-1.0$ & $0.2-0.7$ & $0.2-0.5$ \\
\hline Substrate framework & Boulder/cobble & Cobble/boulder & Cobble/gravel & Cobble/gravel & Gravel/cobble & Gravel/cobble \\
\hline Spawning locations & $\begin{array}{l}\text { Gravel pockets, pool } \\
\text { tails }\end{array}$ & $\begin{array}{l}\text { Gravel pockets, lateral } \\
\text { bars, side channels }\end{array}$ & $\begin{array}{l}\text { Lateral bars, gravel } \\
\text { pockets }\end{array}$ & $\begin{array}{l}\text { Lateral bars, gravel } \\
\text { pockets }\end{array}$ & $\begin{array}{l}\text { Gravel riffles, riffle } \\
\text { crests }\end{array}$ & $\begin{array}{l}\text { Gravel riffles, riffle } \\
\text { crests }\end{array}$ \\
\hline \multicolumn{7}{|l|}{ Scour monitors } \\
\hline Selected & 7 & 7 & 10 & 8 & 11 & 12 \\
\hline Nonselected & 5 & 11 & 8 & 0 & 10 & 7 \\
\hline Catchment area, $\mathrm{km}^{2}$ & 12.8 & 88.4 & 35.6 & 52.0 & 105.4 & 56.7 \\
\hline Elevation range, $\mathrm{m}$ & $549-2134$ & $488-2134$ & $305-1524$ & $274-1524$ & $475-1644$ & $475-1341$ \\
\hline \multirow[t]{2}{*}{ Reach coordinates } & $47^{\circ} 55^{\prime} 10.93^{\prime \prime} \mathrm{N}$ & $47^{\circ} 54^{\prime} 11.02^{\prime \prime} \mathrm{N}$ & $47^{\circ} 28^{\prime} 27.16^{\prime \prime} \mathrm{N}$ & $47^{\circ} 27^{\prime} 1.99^{\prime \prime} \mathrm{N}$ & $47^{\circ} 22^{\prime} 12.03^{\prime \prime} \mathrm{N}$ & $47^{\circ} 22^{\prime} 17.67^{\prime \prime} \mathrm{N}$ \\
\hline & $121^{\circ} 18^{\prime} 38.03^{\prime \prime} \mathrm{W}$ & $121^{\circ} 18^{\prime} 59.70^{\prime \prime} \mathrm{W}$ & $123^{\circ} 26^{\prime} 56.91^{\prime \prime} \mathrm{W}$ & $123^{\circ} 25^{\prime} 45.15^{\prime \prime} \mathrm{W}$ & $121^{\circ} 37^{\prime} 25.63^{\prime \prime} \mathrm{W}$ & $121^{\circ} 41^{\prime} 16.76^{\prime \prime} \mathrm{W}$ \\
\hline Catchment geology & $\begin{array}{l}\text { Metamorphic rock, } \\
\text { granodiorite, volcani- } \\
\text { clastic deposits }\end{array}$ & $\begin{array}{l}\text { Metamorphic rock, } \\
\text { granodiorite, volcani- } \\
\text { clastic deposits }\end{array}$ & $\begin{array}{l}\text { Marine sandstone, } \\
\text { marine basalt, gla- } \\
\text { cial-fluvial terrace } \\
\text { deposits }\end{array}$ & $\begin{array}{l}\text { Marine sandstone, } \\
\text { marine basalt, gla- } \\
\text { cial-fluvial terrace } \\
\text { deposits }\end{array}$ & $\begin{array}{l}\text { Volcaniclastic depos- } \\
\text { its, andesite flows, } \\
\text { Quaternary alluvium }\end{array}$ & $\begin{array}{l}\text { Volcaniclastic depos- } \\
\text { its, andesite flows, } \\
\text { Quaternary alluvium }\end{array}$ \\
\hline Land-use history & Mostly wilderness & $\begin{array}{l}\text { Wilderness, logging/ } \\
\text { roads }\end{array}$ & Mostly wilderness & $\begin{array}{l}\text { Logging/roads, wilder- } \\
\text { ness }\end{array}$ & $\begin{array}{l}\text { Logging/roads, water } \\
\text { supply }\end{array}$ & $\begin{array}{l}\text { Logging/roads, water } \\
\text { supply }\end{array}$ \\
\hline
\end{tabular}


and well connected with abundant side channels created by large LWD jams or overflow channels. The forced step - pool tributary Goblin Creek is a steep-gradient, cobbleand boulder-bed channel, where pools are forced by LWD jams, boulder obstructions, and bedrock. The armoured cobble- and boulder-bed thalwegs and periodic marginal deposits of gravel in these channel types suggest that gravel particles are supply-limited (sensu Bravo-Espinosa et al. 2003) and only persist in local zones of reduced unit stream power. Char spawning typically occurs on lateral bar gravel deposits, pocket gravels above or below obstructions, and in side channels.

The forced pool-riffle reaches of the SF Skokomish River in the southern Olympic Mountains are moderategradient, cobble-bed channels with pools forced by LWD or boulders. These reaches are laterally active with side channels and occasional braids, which build coarse-grained floodplains and erode into glacial-fluvial terrace deposits. The supply of gravel-sized particles is from highly episodic mass wasting and terrace erosion. Transient gravel patches overlying an armoured cobble and boulder bed suggest that gravel particles are supply-limited in these reaches with abundant stream power (sensu Bravo-Espinosa et al. 2003). Char spawning typically occurs on lateral bar gravel deposits or pocket gravels above or below obstructions.

\section{Hydrology of study reaches}

In the Cedar and Rex rivers, hydrologic data are available from existing US Geological Survey (USGS) stream gages within the study reaches. In the NF Skykomish and SF Skokomish catchments, existing USGS gages were more than $30 \mathrm{~km}$ downstream. Therefore, automatic stage recorders were installed along study reaches with adequate local-scale $(1-10 \mathrm{~m})$ and reach-scale $(\sim 100 \mathrm{~m})$ geomorphic control (Goblin Creek (NF Skykomish) and SF Skokomish River above Church Creek). Stage-discharge rating curves were developed for each gage according to standard techniques (Rantz 1982).

At USGS gages (Cedar and Rex rivers), the frequency or recurrence interval (RI) of annual peak discharge magnitudes was calculated from gage records in Sumioka et al. (1998). At non-USGS gages, the event frequency was estimated from regional regression equations using basin area and basin mean annual precipitation developed by Sumioka et al. (1998). Flood frequency regression data at non-USGS gages had standard error of prediction of $\pm 50 \%$. Therefore, flood frequency values at downstream USGS gages were used to validate estimates at non-USGS gages upstream.

\section{Bedload scour and fill measurements}

Sliding-ball scour monitors were used to measure scour and fill. They consisted of durable perforated-plastic golf balls, $4 \mathrm{~cm}$ in diameter, strung on $3 \mathrm{~mm}$ stainless steel cable, attached to an anchor, and inserted into the streambed (Schuett-Hames et al. 1999; DeVries 2000). Scour and fill depths were measured at $4 \mathrm{~cm}$ intervals, with an estimated error of $\pm 2.5 \mathrm{~cm}$, which is slightly larger than that reported by DeVries (2000) due to an uneven heterogeneous bed. Scour and fill depths were measured both incrementally (i.e., from individual floods) and cumulatively (from multiple flood events). The cumulative maximum scour or fill depth for the incubation season is defined as the maximum extent of scour or fill over the period regardless of smaller, intermediate cycles of scour and fill. In minor flood situations where scour was less than the distance to the first scour monitor ball, only net scour or fill could be measured.

Ninety-six scour monitors were installed in the three main catchments (Table 1). Fifty-five monitors were located adjacent to selected bull char redd sites and 41 were located at nonselected sites (see local site selection below). Reference points on all scour monitors were surveyed into local benchmarks to determine their relative elevation and bed elevations after each event. Thirty-four permanent elevational transects were (re)surveyed at scour monitor locations to document net cross-sectional channel change and the stability of scour monitors following distinct flood events. All sites were monitored over two water years (WY) and incubation seasons: WY 2001 and WY 2002. Sites on the Cedar and Rex rivers also were monitored into WY 2003 and WY 2004 to include a wider range of temporal variation in flood magnitude at these sites.

\section{Local site selection}

Scour monitors were installed during late summer 2000 and 2001 prior to spawning to avoid disturbing adults or eggs. A grid pattern of scour monitors (Schuett-Hames et al. 1999) was not used because of the unsuitability of much of the coarse substrate for spawning and the low density of bull char spawning activity. Scour monitor and transect installation locations were chosen according to qualitative assessment of potential char spawning sites (based on depth, velocity, substrate, cover, habitat unit) and local advice from fisheries biologists on recent past (1-2 years) spawning locations. Scour data from only one monitor per spawning patch was used in the analysis.

After fall spawning, scour monitor sites were classified as either selected (S) by bull char or nonselected (NS). Scour data were discarded under the rare instance that monitors were disturbed by spawning fish $(n=3)$. Sites designated as selected were within $2 \mathrm{~m}$ of the redd pit within the same homogenous substrate patch, under the assumption that scour processes were similar between the redd and adjacent bed (Rennie and Millar 2000). Nonselected sites were typically not representative of high quality bull char spawning sites based on habitat-preference data (i.e., depth, velocity, substrate size, distance to wetted edge, distance to cover, temperature, vertical hydraulic gradient) collected during spawning conditions and reported in Shellberg (2002). However, nonselected sites were generally suitable for salmonid spawning as many had been locations of redds by other salmonids in other years (e.g., Oncorhynchus kisutch, personal observation by J. Shellberg). Nevertheless, nonselected sites did not represent the full range of habitat conditions throughout a spawning reach (which were not systematically sampled), but were biased toward sites assessed a priori to have a higher probability of spawning.

The site-selection parameters used are distance to wetted edge and proximity to cover (hydraulic obstructions), both normalized by wetted width. These variables were chosen because of their relation to the main hypothesis that scour is reduced by the availability and selection of stable refugia habitat provided by channel margins or in-channel obstruc- 
tions. Owing to a lack of systematic sampling of reach habitat conditions, distances to cover and wetted edge were normalized to channel dimensions.

All scour monitor sites (selected and nonselected) were classified by hydraulic habitat unit type (Barta et al. 1994). Based on observations at all stages, hydraulic habitat units were classified as either (i) gravel pockets upstream of obstructions, (ii) gravel pockets downstream of obstructions, (iii) lateral bars, (iv) straight bars (riffle crests and riffles), or (v) side channels. Obstructions consisted of single large wood pieces, LWD jams, or large boulders $(>1024 \mathrm{~mm})$. Neither scour monitors nor redds were located immediately under or around obstructions where much localized vortex scour typically occurs. All five hydraulic habitats were not always present in each channel type.

\section{Channel hydraulics}

At specific scour monitor sites and longitudinally up- and down-stream, Velcro crest gages (DeVries 2000) were established along channel margins to determine maximum stage heights and water surface slopes. Continuous stage data were established for each crest gage from their relationships with nearby continuous stream gages. Water surface slopes were measured for discharge events at a local scale $(12 \mathrm{~m}$ centered on cross section) and a reach scale $(120 \mathrm{~m})$.

Total boundary shear stress, $\tau_{0}\left(N \cdot \mathrm{m}^{-2}\right)$, was estimated at each scour monitor site using the depth-slope product:

$$
\tau_{0}=\rho_{\mathrm{w}} g d S
$$

where $\rho_{\mathrm{w}}$ is the fluid density $\left(\mathrm{kg} \cdot \mathrm{m}^{-3}\right), g$ is the acceleration of gravity $\left(\mathrm{m} \cdot \mathrm{s}^{-2}\right), d$ is the local flow depth $(\mathrm{m})$, and $S$ is the local water surface slope $\left(\mathrm{m} \cdot \mathrm{m}^{-1}\right)$. Equation 1 assumes a steady uniform flow, a flow depth equal to the hydraulic radius in a wide, rectangular channel, and a water surface slope equal to the friction slope (Henderson 1966). Local water surface gradient was used as the appropriate gradient to estimate shear stress (Zimmermann and Church 2001).

In mountainous or forested channels, actual or effective bed shear stress can be reduced by momentum and energy losses due to obstructions, bed forms, bank friction, channel bends, and channel width changes (Buffington and Montgomery 1999a). Initial attempts were made to estimate local effective bed shear stress during flood events using vertical velocity profiles (e.g., Wilcock 1996); however, snow and road closures hampered access during all but a few flood events. Furthermore, total shear stress estimates were not partitioned mathematically because of the lack of supporting data in highly complex mountain channels. Thus, analyses of the driving forces of sediment transport were restricted to total shear stress and flood magnitude-frequency.

Total shear stress measurements were nondimensionalized for comparison by using the Shields' equation:

$$
\tau^{*}=\frac{\tau_{0}}{D_{50}\left(\rho_{\mathrm{s}}-\rho_{\mathrm{w}}\right) g}
$$

where $\tau^{*}$ is the dimensionless Shields' parameter, $\tau_{0}$ is the total boundary shear stress $\left(N \cdot \mathrm{m}^{-2}\right), \rho_{\mathrm{s}}$ and $\rho_{\mathrm{w}}$ are the sediment and fluid densities $\left(\mathrm{kg} \cdot \mathrm{m}^{-3}\right), g$ is the acceleration of gravity $\left(\mathrm{m} \cdot \mathrm{s}^{-2}\right)$, and $D_{50}$ is the median bed-surface grain size (m) (Henderson 1966). Substrate size distributions in se- lected and nonselected spawning patches were measured during low discharge periods. Pebble counts consisted of at least 100 particles located entirely in local, relatively homogenous substrate patches (Kondolf 1997), excluding withinpatch areas disturbed by spawning.

\section{Statistical analysis}

Differences in cumulative maximum scour depths between hydraulic habitat units were analyzed using the nonparametric Kruskal-Wallis (KW) one-way analysis of variance because of small sample sizes, unequal variances, and non-normality. The $\chi^{2}$ distribution was used instead of the Kruskal-Wallis $H$ distribution because of the differing sample sizes (Zar 1999). Differences in scour depth between habitat types were assessed within the selected and nonselected groups but were not compared between groups (selected vs. nonselected) because of the varying representativeness of nonselected sites. The KW test was also used to compare normalized distance to wetted edge distributions with a uniform distribution, representing no selection preference. Linear regression $t$ tests were used to determine whether regression slopes were significantly different from zero. All statistical results were considered to be significant at $\alpha \leq 0.05$.

\section{Results}

\section{Hydrology}

Bedload scour and egg mortality within salmonid redds are highly dependent on the probability of peak flood events occurring during the incubation period (October to March). Shellberg (2002) and Gibbins et al. (2008) provide an assessment of discharge regimes in regional bull char catchments and determine the inherent probabilities of flooding during incubation. From their analysis, catchments dominated by rain or rain-on-snow peak flood events such as the SF Skokomish River have a high probability of peak discharges occurring during the incubation period of bull char. Catchments at a slightly higher elevation such as the upper Cedar and Skykomish rivers have a moderate probability of peak discharges occurring during this period because of the influence of seasonal snow packs. The timing of different flood events and their different flood-producing mechanisms (rain, rain-on-snow, snowmelt) are evident in the study area hydrographs (Fig. 1).

During the study period, WY 2001 was one of the driest winters on record, with peak discharges at or less than the 1year recurrence interval (RI) in all study catchments. In contrast, WY 2002 had normal precipitation and discharge, and WYs 2003 and 2004 experienced above-average precipitation and peak discharge (Fig. 1).

\section{Local bedload scour at redd sites}

During the WY 2001 drought (Fig. 1), minimal bedload transport at all selected (S) and nonselected (NS) scour monitor sites resulted in shallow scour depths $(<5 \mathrm{~cm})$, lack of channel change, and high survival to emergence of char (e.g., Stutsman and Ogg 2002). After additional spawning site selection during the WY 2002 char spawning season, sites selected by bull char during both WY 2001 and WY 2002 were combined as one data set for analysis because of 
Fig. 1. Instantaneous discharge $\left(\mathrm{m}^{3} \cdot \mathrm{s}^{-1}\right)$ during study period: (a) Cedar River (USGS 12115000), (b) Rex River (USGS 12115500), (c) Goblin Creek (North Fork Skykomish), (d) Skykomish River (USGS 12134500), (e) South Fork Skokomish above Church Creek, ( $f$ ) South Fork Skokomish (USGS 12060500). Note that the $x$ and $y$ axes have different scales for different gage sites. RI, flood recurrence interval (years).

(a)

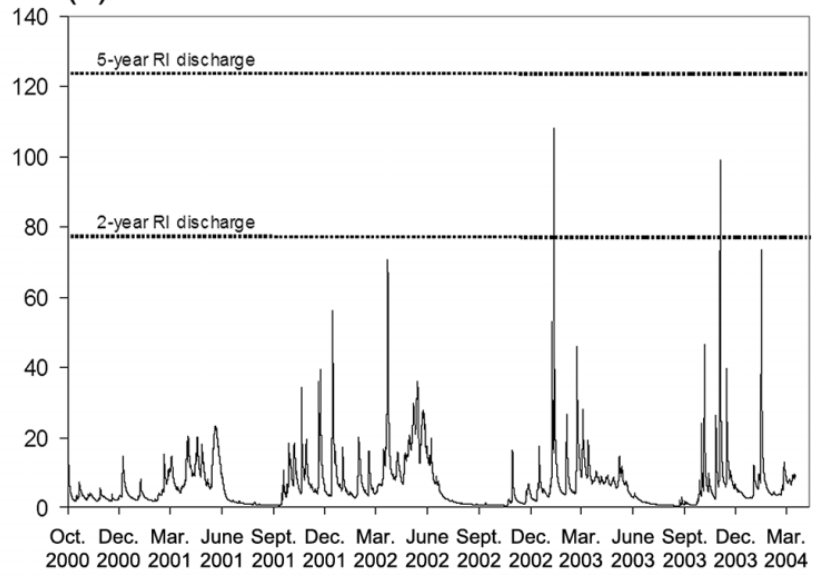

(c)

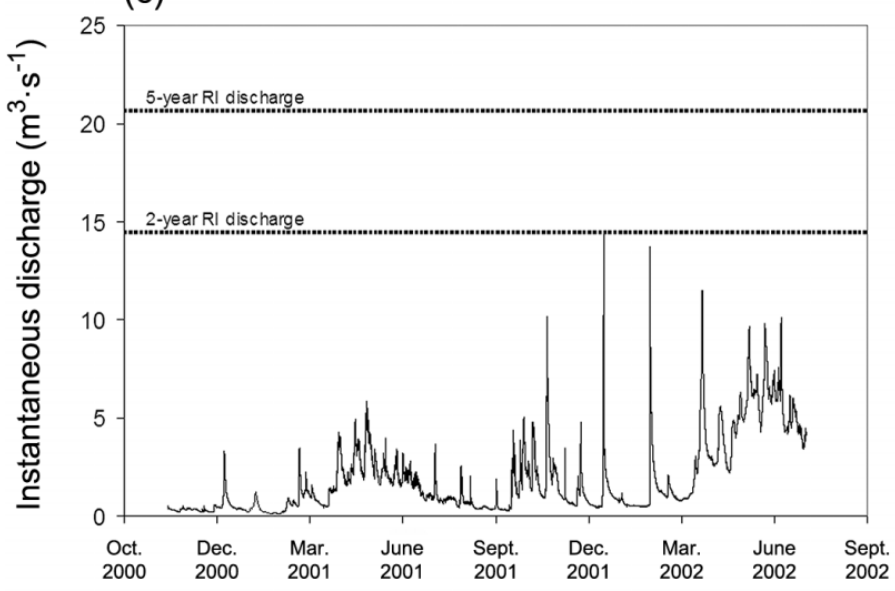

(e)

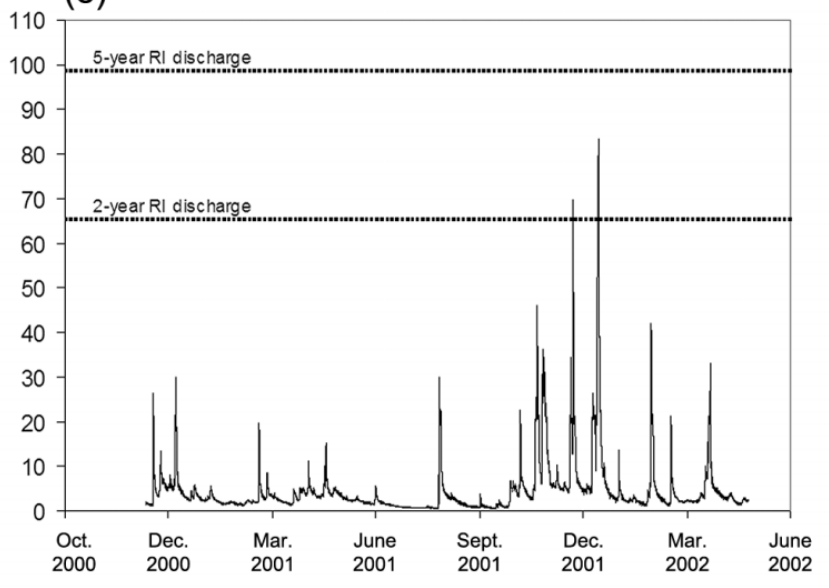

(b)

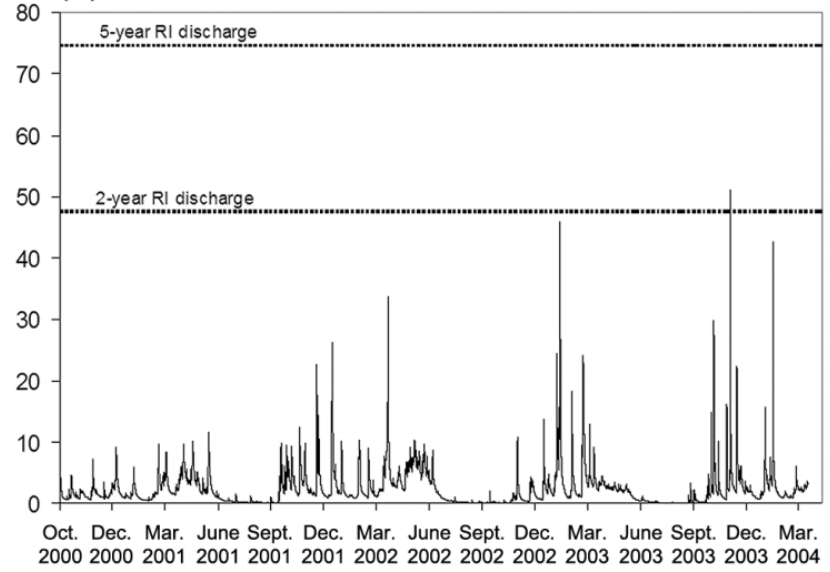

(d)

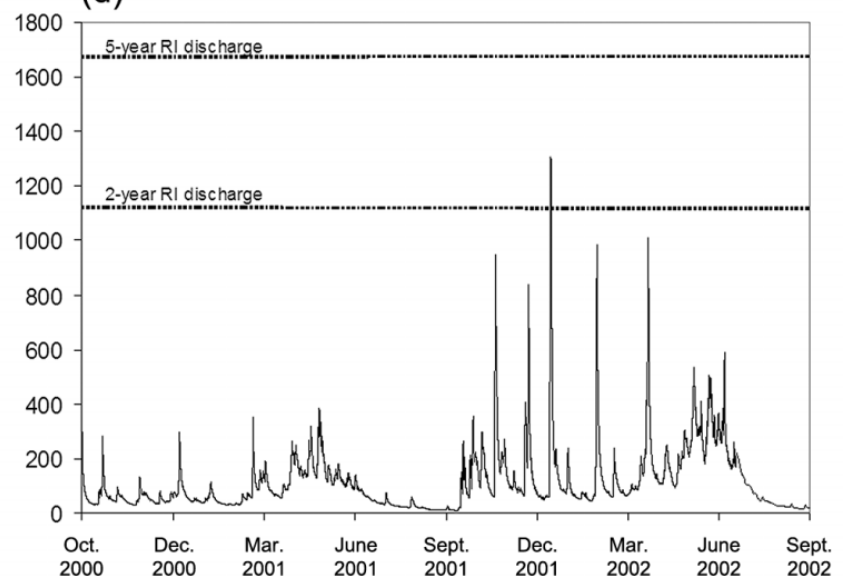

(f)

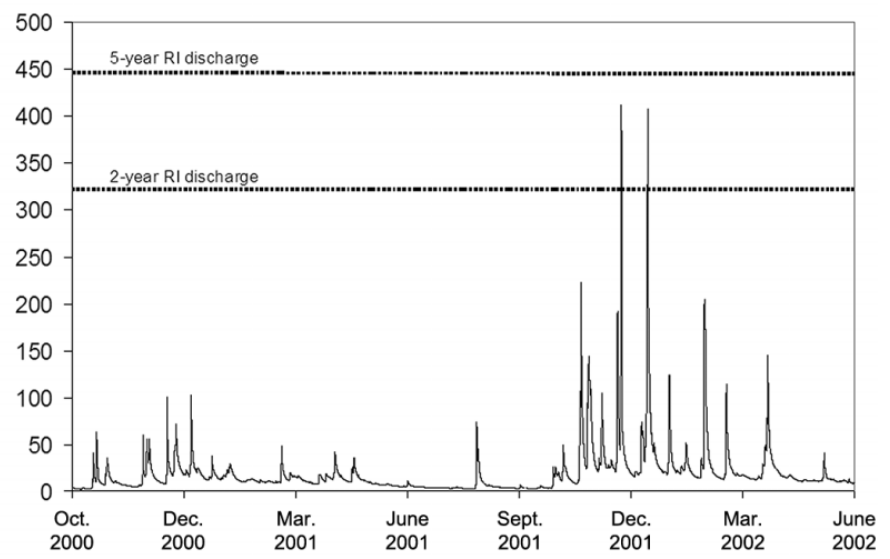

\section{Date}


the low number of selected sites for any given year and the unchanged bed morphology from the previous year.

\section{NF Skykomish River}

Three flood events (14 November 2001, 7 January 2002, and 22 February 2002) occurred during WY 2002 (Figs. $1 c-d$ ), which had RIs ranging from approximately 1 to 3 years. The cumulative maximum scour depth for the entire WY 2002 winter egg incubation period (October to March) was significantly different between hydraulic habitat units selected (KW $p \leq 0.03)$ and not selected (KW $p \leq$ 0.02 ) by bull char (Fig. 2a). Among selected sites, lateral bars experienced the greatest scour depths $(>10-15 \mathrm{~cm})$ at or beyond cited egg burial depths (DeVries 1997). Sites downstream of obstructions such as LWD and boulders had moderate amounts of scour (generally $<10 \mathrm{~cm}$ ), whereas selected side-channel spawning sites were stable with a tendency toward fill. These results support the hypothesis that specific hydraulic habitat units such as side channels and units near obstructions can provide incubation environments with reduced scour.

\section{SF Skokomish River}

Cumulative maximum scour depths during WY 2002 were dominated by events on 16 December 2001 and 7 January 2002, which were both between the 2- and 4-year RI. Scour depths at many selected and nonselected sites were at or well beyond the $10-15 \mathrm{~cm}$ cited egg burial depths (Fig. $2 b$ ), indicating that substantial egg loss could result at these discharge magnitudes, as supported by Stutsman and Ogg (2002). Selected sites upstream of LWD obstructions experienced significantly less scour (KW $p \leq 0.02$ ), as these sites continued to be deposition zones for locally eroded gravel. Sites downstream of obstructions were initially stable in December 2002, but eventually scoured during the observed mobility of modest diameter LWD. Although these results partially support the hypothesis that obstructions can provide incubation environments with reduced scour, they also demonstrate that site-specific discharge thresholds exist at which in-channel obstructions can become mobilized (especially modest-sized LWD), ending their role as energy and scour reducers.

\section{Upper Cedar River}

Scour and channel change were monitored for two additional years in the Cedar and Rex rivers (WYs 2003 and 2004), providing additional data for the relationship between scour depth and flood recurrence interval. Cumulative maximum scour depths during both WY 2001 and WY 2002 were shallower than cited egg burial depths except for a few extremes (Fig. 3). Cumulative maximum scour during WY 2002 was dominated by one flood event on 14 April 2002 (Cedar River, 1.8-year RI; Rex River, 1.3-year RI), when slight fill was just as common as scour and a majority of the bed was not mobilized. During WYs 2001 and 2002, abundant production of bull char was determined from qualitative observations of juveniles (J.G. Shellberg and local biologists' personal observations). Each year from 2001 to 2004 generally had progressively higher peak discharge magnitudes (Figs. $1 a$ and $1 b$ ) resulting in progressively deeper scour depths at or beyond the $10-15 \mathrm{~cm}$ egg burial
Fig. 2. Cumulative maximum scour or fill depth at (a) North Fork Skykomish River and Goblin Creek during WY 2002 (maximum 2.0 - to 2.7-year flood recurrence interval (RI)), and (b) South Fork Skokomish River during WY 2002 (maximum 3.8-year RI). Negative values represent cumulative fill. $N$, sample size; $\mathrm{S}$, selected (darker shaded boxes); NS, nonselected (lighter shaded boxes).

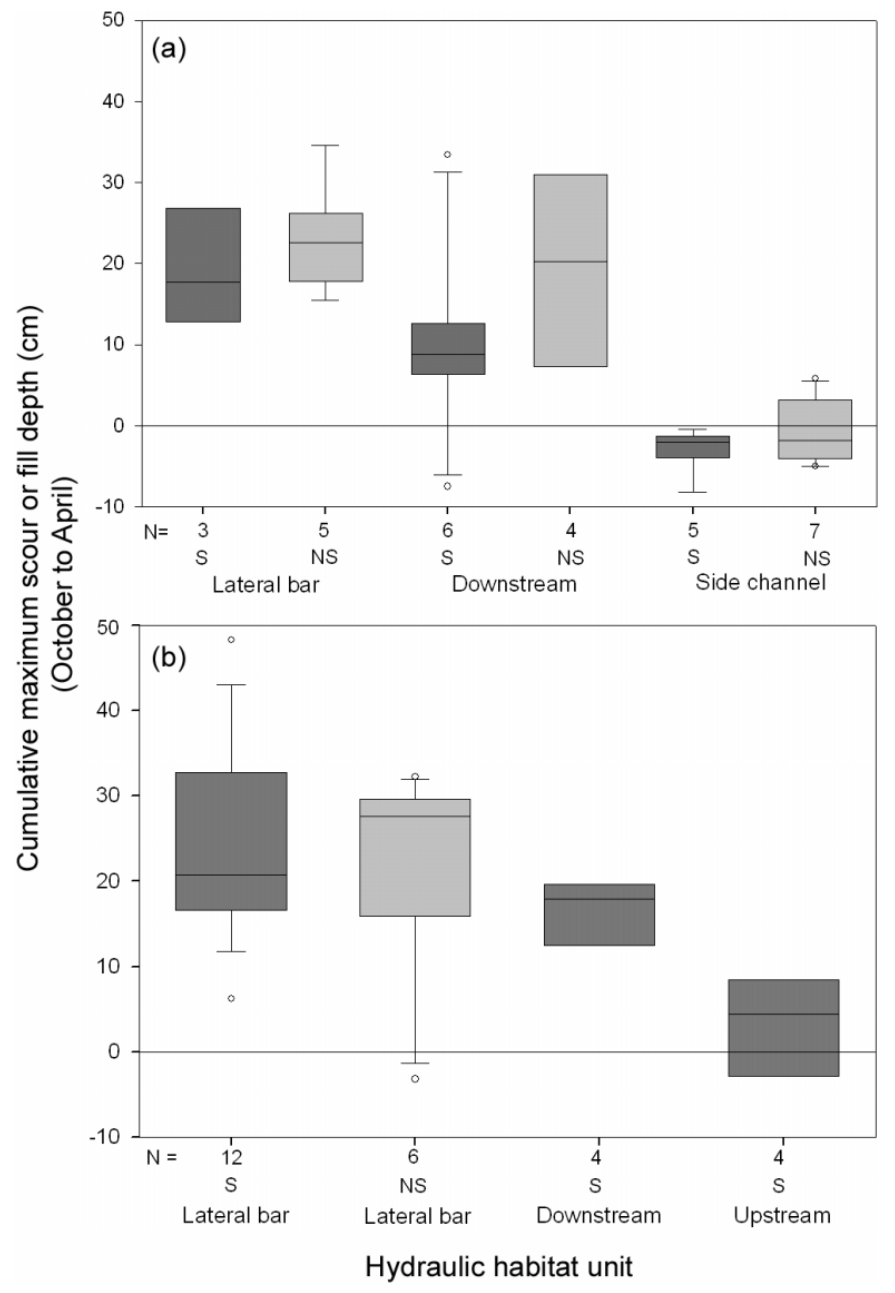

range during WY 2004 (Fig. 3). However, this deep scour (>15 cm; Fig. 3) was only common during 2004, which had the highest flood durations above the 1.5-year RI during the study (see below). Data from 2001-2003 support the bed scour hypothesis that vertical refugia may exist below $2 \cdot D_{90}$ during common flood events in partially transport-limited, pool-riffle channel types with abundant gravel and local gravel armour layers.

\section{Shear stress at scour monitor sites}

In the NF Skykomish catchment, scour depth data at sidechannel, downstream, and lateral bar habitat units were correlated as one group against estimates of total bed shear stress from the depth-slope product during the largest flood event in WY 2002 (7 January 2002) (Fig. 4). Although the above habitat units were characterized by systematically different local shear stresses, the units were situated on an increasing gradient of exposure to shear stress, as supported by local velocity profiles in Shellberg (2002). Therefore, they were analyzed together to develop a common relation- 
Fig. 3. Cumulative maximum scour depth at the Cedar and Rex rivers along straight bars (riffle crests and riffles) during WY 2001 to WY 2004. N, sample size; RI, flood recurrence interval (years); S, selected (darker shaded boxes); NS, nonselected (lighter shaded boxes).

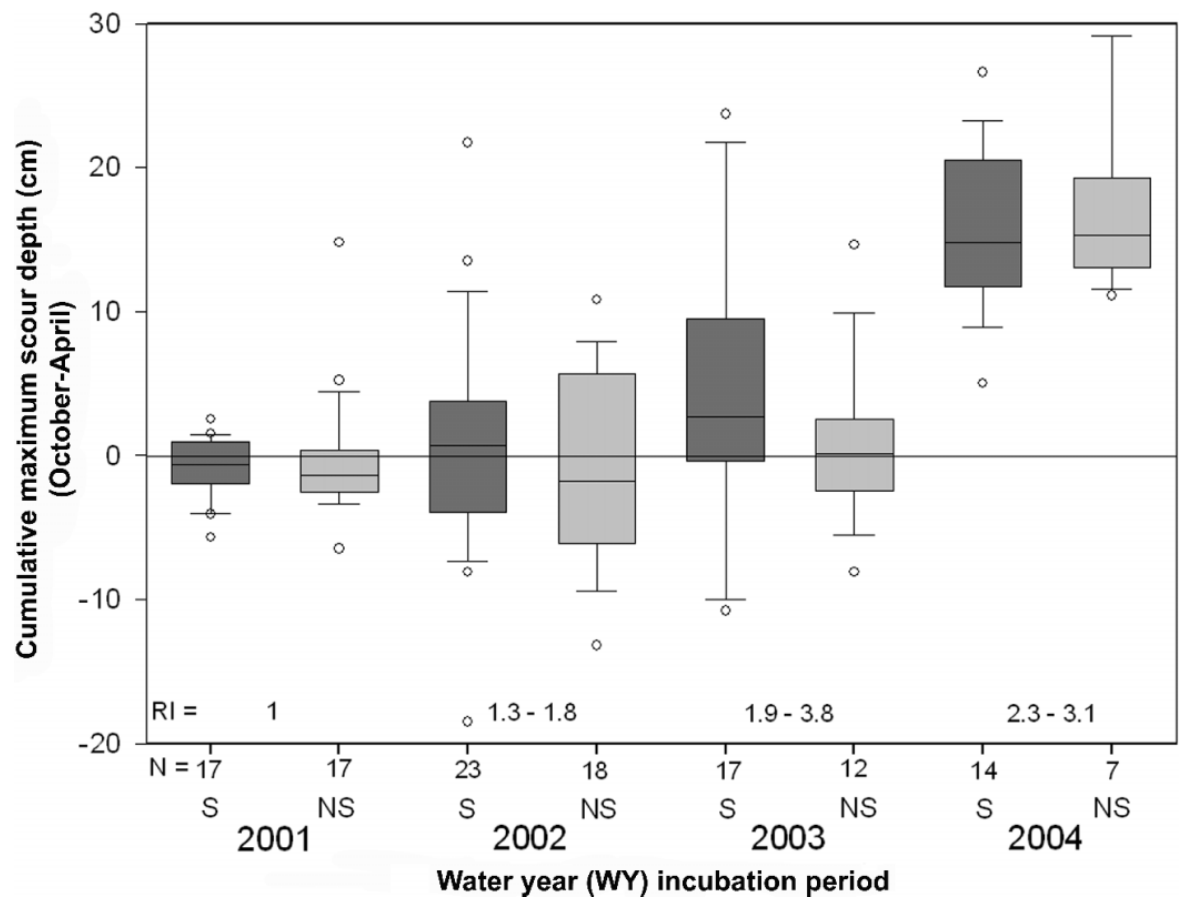

Fig. 4. North Fork Skykomish River and Goblin Creek scour depth (scaled to $D_{90}$ ) vs. total dimensionless shear stress during the largest flood event during WY 2002 (2.0- to 2.7-year flood recurrence interval). Lateral bar (open squares), side channel (plus signs), downstream (open diamonds).

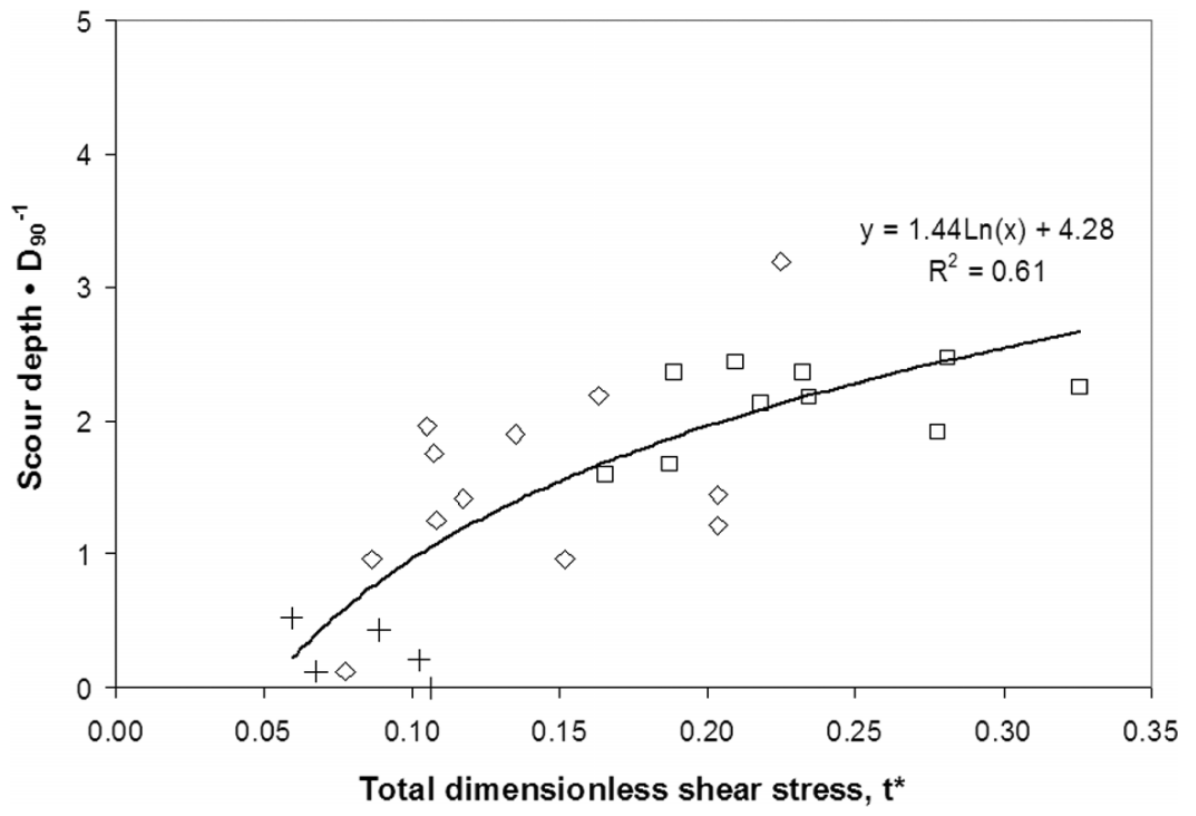

ship between shear stress and scour depth (Fig. 4). Overall, the surface of lateral bars had the highest total shear stress estimates and experienced the deepest scour, but deep scour beyond $2.5 \cdot D_{90}$ was uncommon. The best-fit logarithmic trend suggests an asymptotic trend with a limit on potential scour depth; however, this needs to be confirmed by sampling scour over a larger range of discharges and shear stresses than observed in this study. According to these total shear stress estimates, the initiation of scour (motion) began at a dimensionless shear stress value of $\sim 0.05$, similar to values reported elsewhere (Buffington and Montgomery 1997).

In contrast with the NF Skokomish, the relationship between shear stress and scour depth in the SF Skykomish varied between habitat types because of large differences in local depth and slope and presumably differences in energy dissipation (Fig. 5); therefore, units were analyzed separately. In all habitat units, scour depth (scaled to $D_{90}$ ) increased significantly with dimensionless shear stress, but 
Fig. 5. South Fork Skokomish River scour depth (scaled to $D_{90}$ ) vs. total dimensionless shear stress during the largest flood event during WY 2002 (3.8-year flood recurrence interval). Lateral bar (open squares), upstream (asterisks), downstream (open diamonds).

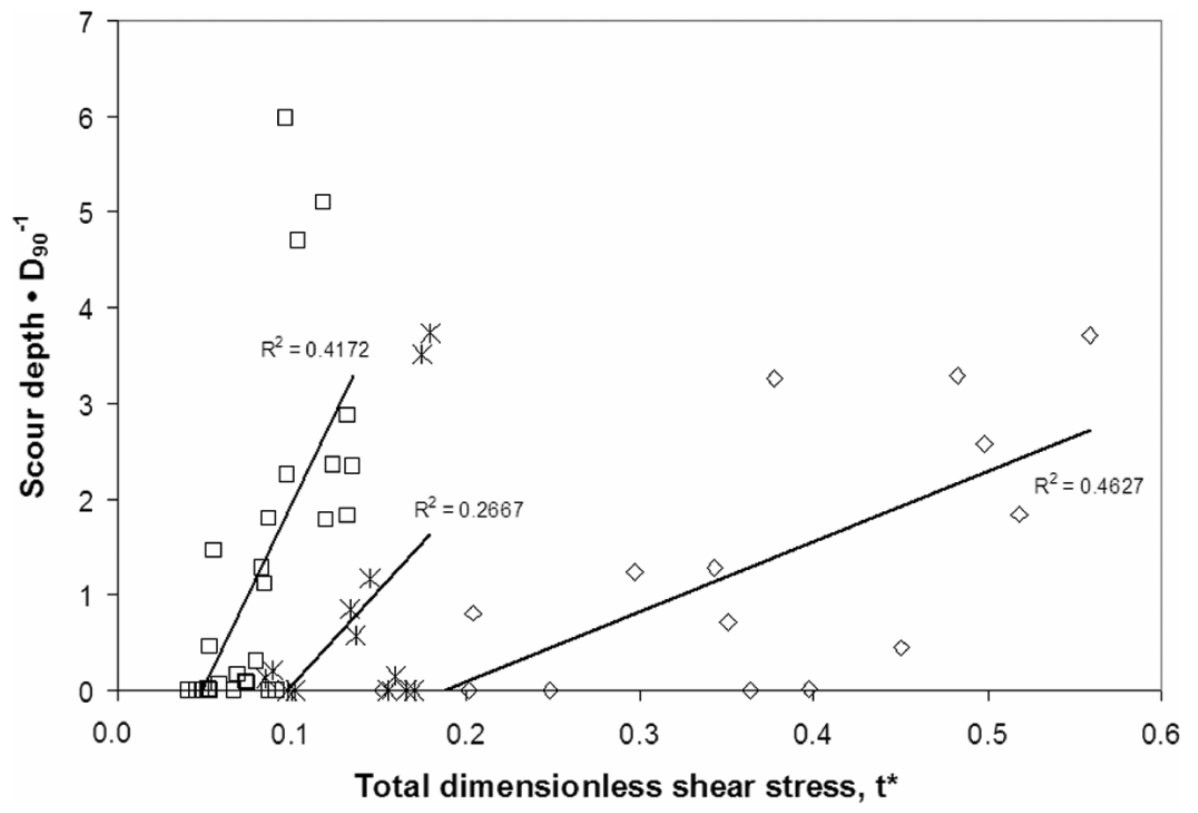

the rate of increase varied among different hydraulic habitat units. Lateral bar sites with relatively little structural energy dissipation had total dimensionless shear stresses closest to the presumed local effective stress (i.e., initiation of scour at $~ 0.05$ ) (Fig. 5). Scour at sites upstream and downstream of obstructions began at higher dimensionless boundary shear stresses of $\sim 0.1$ and 0.2 , respectively, indicating that actual effective shear stresses were greatly reduced by energy dissipation around these structures and (or) that the local depth-slope product greatly overestimated total shear stress in these locales.

In the upper Cedar River reaches, cumulative maximum scour depth increased $\left(r^{2}=0.21, p<0.0001\right)$ with increasing total dimensionless shear stress estimated for the largest flood event of each year (Fig. 6). The initiation of scour (motion) also began at dimensionless shear stress values near $\sim 0.05$, which was likely due to the dearth of obstructions influencing energy loss in these pool-riffle channel types. However, the variability in the relationship between scour and shear stress was considerable due to the tendency for both scour and fill in these channel types, plus the lack of more precise data on local sediment supply imbalances and local effective shear stress.

Despite the lack of local effective shear stress measurements, total shear stress measurements applied locally in these different channel types and hydraulic habitat units demonstrate that both shear stress and scour are reduced in spawning gravels near in-channel obstructions and in side channels. These habitats provide scour refugia for incubating bull char embryos according to the main hypothesis. Data from the pool-riffle channels of the upper Cedar River highlight that other factors beyond obstructions can influence shear stress and resultant scour and fill, e.g., alternating bedforms (pools and riffles) and storage of abundant gravel.

\section{Reach-scale bed mobility}

In the NF Skykomish catchment, data from elevational transects before and after floods confirmed that the framework structure of the channel bed (i.e., large interlocked cobbles and boulders) was stable during common flood events (<3-year RI). Annual net change in cross-sectional area ranged from $-1.3 \%$ to $4.4 \%$ (median of $1.1 \%, n=6$ ) (positive values indicate degradation). However, local exposed and unprotected gravels in lateral bars were mobile and experienced scour (Fig. 2a), indicating a different threshold of mobility for habitat units with contrasting particle sizes (e.g., Gintz et al. 1996; Zimmermann and Church 2001).

The transects of the Cedar and Rex rivers also were generally stable in their morphology during four years of monitoring, despite patchy local scour and fill in spawning riffles (Fig. 3). During WY 2002, net annual change in channel cross-sectional area ranged from $-2.3 \%$ to $8.6 \%$ (median of $0.5 \%, n=11$ ). From WY 2003 to WY 2006, cumulative net change in channel cross-sectional area increased (range, $-9.6 \%$ to $14.8 \%$ ), but the median value remained low $(-0.3 \%, n=11)$. Local gravel armor layers were only breached during events greater than the 2-year RI. It remains unknown whether larger discharges (i.e., >4.0-year RI) would produce even greater channel change and scour depths, or whether this relationship would break down because of the difficulty of shearing abundant gravel to great depths in pool-riffle channel types (DeVries 2000, 2008).

In contrast to other catchments, the SF Skokomish transects showed considerable reach-scale bed mobility. Above Church Creek, temporary sediment transport imbalances were associated with eroding terrace deposits at cut banks. Initial aggraded material (sand, gravel, cobble, LWD) was stable and attractive to spawning bull char in an otherwise coarse cobble-bedded reach. Spawning gravels were partially unstable during the first few floods of the year (1- to 2year RI), when the change in cross-sectional area ranged from $-2.7 \%$ to $7.4 \%$ (median, $1.9 \% ; n=5$ ). These gravels were later exported during larger events (3.8-year RI), re- 
Fig. 6. Cedar and Rex rivers cumulative maximum scour depth (scaled to $D_{90}$ ) vs. total dimensionless shear stress at straight bars (riffle crests and riffles) during the largest flood event of each year from WY 2001 to WY 2004 (maximum 3.8-year flood recurrence interval).

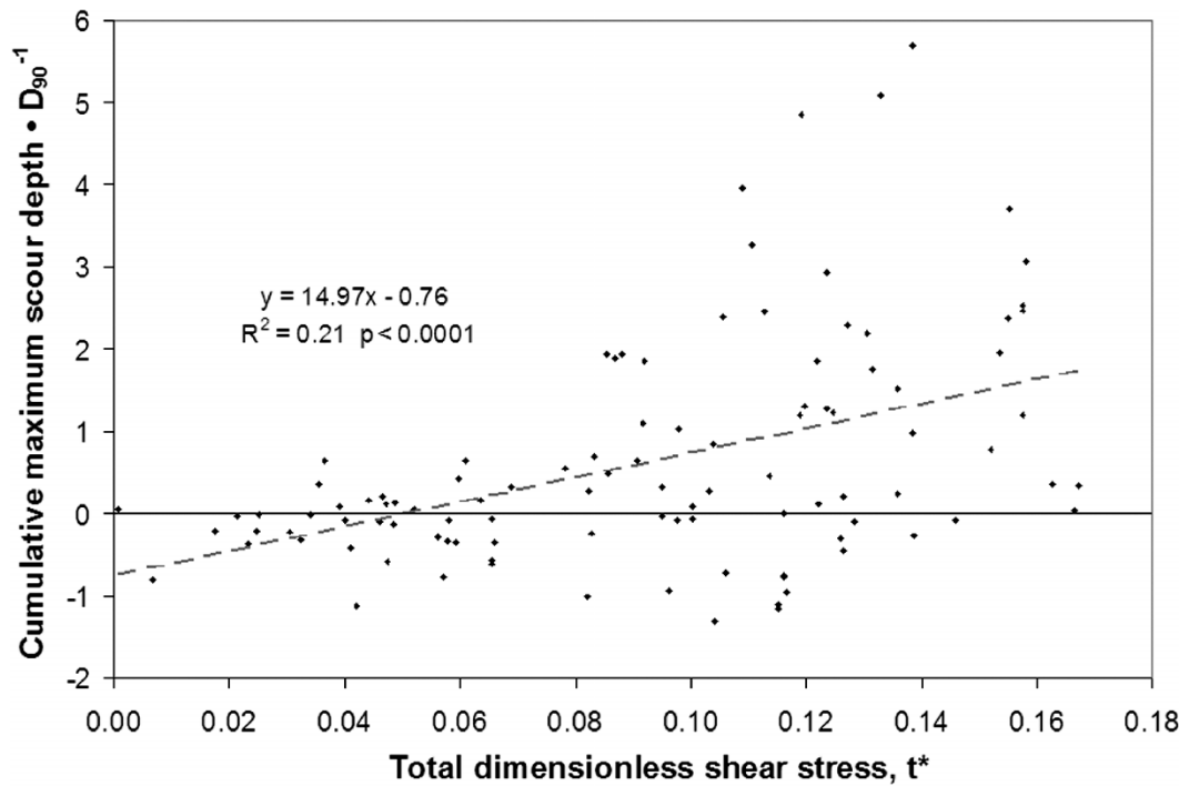

sulting in scour (Fig. $2 b$ ) and net increases in cross-sectional area (range, $-16.6 \%$ to $19.3 \%$; median, $6.0 \% ; n=5$ ). Newly recruited sediment from terrace deposits re-initiated the cycle of bed aggradation and degradation. Below Church Creek, additional coarse and fine sediment was delivered from both upstream terrace cut bank erosion and anthropogenically enhanced erosion of landslide material (e.g., Church Creek). This reach adjusted more frequently to its imposed sediment supply, resulting in initial scour at or beyond the cited egg burial depths (Fig. 2b), which was later followed by massive aggradation and decreases in net crosssectional area (range, $-15.0 \%$ to $-69.6 \%$; median, $-58.0 \%$; $n=5)$.

These channel change data suggest that hydrogeomorphic conditions beyond local in-channel obstructions or egg burial depth can influence embryo vulnerability to scour and fill, specifically the stochastic supply, storage, and transport of sand and gravel bed material. Thus, local refugia at the reach scale may be inadequate for scour protection in isolation, and channel segment or subcatchment scale refugia may play an important role.

\section{Redd site selection and scour refugia}

Redd distances to wetted edge, normalized by wetted width, were typically less than 0.30 for both the NF Skykomish and upper Cedar sites, suggesting that fish generally avoided the center $40 \%$ of these channels. However, selected sites did not have distributions significantly different from a uniform distribution (NF Skykomish, KW $p>0.5$; upper Cedar, KW $p<0.12$ ), indicating that any width selection preference was slight. In contrast, the SF Skokomish had normalized distances to wetted edge values less than 0.10 . Selected sites differed significantly (KW $p<0.0001$ ) from a uniform distribution, suggesting a strong selection preference for channel margins. However, avoidance of deep thalwegs in the SF Skokomish also was partially influenced by limited gravel availability in these areas.
Redd distance to cover was largest in the pool-riffle reaches of the upper Cedar River (median, $12.2 \mathrm{~m}$; range, 1.2-21.3 m), where the forced pool-riffle channels of the NF Skykomish (median, $2.9 \mathrm{~m}$; range, 1.8-5.5 m) and SF Skokomish (median, $5.5 \mathrm{~m}$, range $2.3-8.8 \mathrm{~m}$ ) had lower values. In comparison to available habitat, values normalized to wetted width were lowest in the SF Skokomish (median, 0.21; range, 0.16-0.49), intermediate in the NF Skykomish (median, 0.55; range, 0.07-0.70), and highest in the upper Cedar River (median, 0.62; range, $0.10-1.09$ ).

Site selection in proximity to potential scour refugia (channel margins or obstructions) was most pronounced in the SF Skokomish River, less pronounced in the NF Skykomish, and relatively absent in the pool-riffle reaches of the upper Cedar River. It is interesting to note that the scour sites and reaches in the SF Skokomish in the Olympic Mountains had the deepest scour depths, the greatest degree of reach-scale bed mobility, and the most inhospitable discharge regime (Figs. 1e, $1 f$; Gibbins et al. 2008), supporting the hypothesis that bull char were actively selecting spawning sites to avoid redd scour.

\section{Flood discharge and scour}

The three catchments and channel types had median scour depths at or beyond the cited egg burial depths $(10-15 \mathrm{~cm})$ during 2- to 4-year RI events, suggesting that bull char redds are indeed vulnerable to scour during common flood events. When grouping scour data for all study sites, positive trends existed for increasing scour or median scour with increasing RI, respectively $\left(r^{2}=0.20, p<0.0001 ; r^{2}=0.70, p<\right.$ 0.0001) (Fig. 7a). However, the distribution of local scour depths differed at the hydraulic habitat unit scale and between channel types (Figs. 2-6), presumably due to variations in local shear stress and sediment supply. The exception of increasing median scour with increasing RI was the Cedar River, where the largest flow magnitude during WY 2003 (3.8-year RI) was higher than during WY 
Fig. 7. (a) Scour depth $(\mathrm{cm})$ versus flood recurrence interval (RI) for all study sites. Shaded broken line represents raw data trend $\left(R^{2}=\right.$ $0.20 ; p<0.0001 ; y=5.37 x-4.06)$. Black continuous line represents median data trend $\left(R^{2}=0.70 ; p<0.0001 ; y=5.81 x-5.70\right)$. $(b)$ Scour depth $(\mathrm{cm})$ versus flood duration (hours) $>1.5$-year recurrence interval (RI) for all study sites. Shaded broken line represents raw data trend $\left(R^{2}=0.21 ; p<0.0001 ; y=0.40 x+1.94\right)$. Black continuous line represents median data trend $\left(R^{2}=0.86 ; p<0.0001 ; y=0.47 x+0.13\right)$.

Small shaded rectangles represent all raw data from all catchments; solid symbols represent median values: triangles, Cedar River; circles, Rex River; diamonds, North Fork Skykomish; squares, South Fork Skokomish.

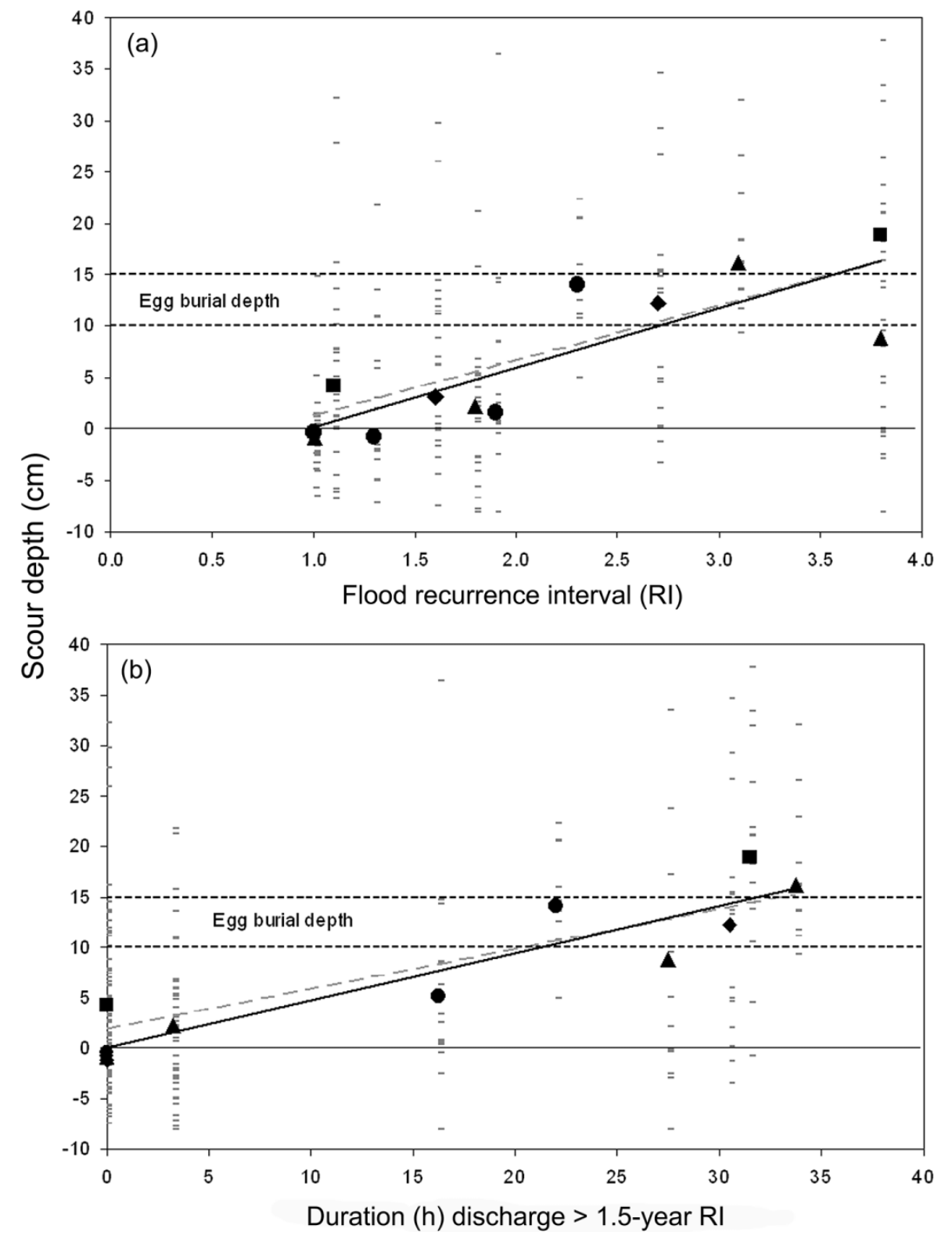

2004 (3.1-year RI) (Fig. 1a), whereas the opposite was true for scour depths. However, the total time duration that discharge exceeded the 1.5-year RI was greater in 2004 than in 2003. Positive trends also existed between scour or median scour and flood duration $\left(r^{2}=0.21, p<0.0001\right.$, and $r^{2}=0.86, p<0.0001$, respectively) (Fig. $7 b$ ). Although total flood duration greater than the 1.5 -year RI is intuitively a more meaningful hydrologic metric to relate to net scour over an entire water year (rather than one peak flood RI value), the correlation with scour only improved slightly, partially due to the positive correlation between annual peak RI and total flood duration $\left(r^{2}=0.73\right)$.

\section{Discussion}

The results show that fall-spawned bull char redds are indeed vulnerable to bedload disturbance and scour in rain or rain-on-snow dominated catchments in western Washington during relatively common flood events (2- to 4-year RI). However, redd scour is dependent on many site-specific hydrogeomorphic factors that vary between different catchments, channel types, habitat units, and discharge and sediment regimes. In support of the main hypothesis, bull char did select sites that provided reduced bedload scour such as local sites near LWD and boulders or in side chan- 
nels created by complex fluvial processes at the reach scale. In addition, egg burial depth below gravel armour layers and typical scour depths appeared to be a viable refuge strategy during common flood events in pool-riffle channel types with few in-channel obstructions. Certain catchment discharge regimes (i.e., winter rain or rain-on-snow dominated), sediment supply regimes (i.e., enhanced mass wasting), reach-scale channel types (i.e., supply-limited reaches), and habitat units (i.e., unprotected gravel patches) appear to be high-risk areas for bull char spawning.

\section{Influence of reach type and local habitat type}

Reach-scale channel type and morphology strongly influenced the type, availability, and stability of local spawning gravel, as suggested by Montgomery et al. (1999) and Buffington et al. (2004). Gravel deposits were more transient in supply-limited reaches (forced pool-riffle and forced step-pool in this study) compared with partially transportlimited reaches (pool-riffle). Forced pool - riffle reaches influenced by locally high but transient gravel supply and reduced wood loads from altered riparian zones had more mobile channel beds than reaches with modest sediment supplies and abundant large wood. Gravel deposits associated with energy dissipating structures (LWD or boulders) experienced reduced scour magnitudes, as suggested by Kondolf et al. (1991) and Barta et al. (1994). In pool-riffle reaches, abundant gravel and local gravel armor layers partially mitigated against deep scour $(>15 \mathrm{~cm})$ beyond egg burial depth (e.g., DeVries 2000, 2002, 2008), implying that other mechanisms besides in-channel obstructions also can provide refugia from egg scour. Quantitative data in the NF Skykomish and qualitative data in the upper Cedar and SF Skokomish catchments indicate that side channels were the most stable spawning areas utilized by bull char due to dampened stream power across complex floodplain habitat.

\section{Site selection}

Bull char spawning site selection indicated a slight to strong preference toward channel margins. Elevational transect and scour data demonstrated that gravel patches along channel center lines and thalwegs were less stable than channel margin areas, especially in compound cross sections, similar to the findings of other studies (Lapointe et al. 2000; Ames and Beecher 2001; Haschenburger 2006). Ames and Beecher (2001) have labeled the relatively scour-free channel margin areas "flood protection zones" (FPZ) because of the high relative survival of salmonid eggs and alevins in these areas. However, in higher gradient channel types, it remains unclear whether spawning site selection is a result of increased spawning gravel availability along channel margins in otherwise coarse channels or selective pressures to avoid sediment transport (scour) along the channel center line during predictable floods (i.e., SF Skokomish). Regardless, there are significant mortality trade-offs between spawning high in a cross section near the channel edge to avoid bedload scour and spawning low in a cross section near the thalweg to avoid redd dewatering or sedimentation (Den Boer 1968; Ames and Beecher 2001; Gibbins et al. 2008).

Successful spawning in pool-riffle reaches with few inchannel obstructions indicates that selection of hydraulic cover is not essential in channel types with generally low scour depths. However, site selection near local cover that provides hydraulic shelter (LWD, boulders) or in reach-scale side channels may enhance the protection of bull char offspring from deep scour, especially in channel types with higher stream power. Where suitable hydraulic complexity exists at the reach scale, it is hypothesized that the wide site selection proclivities of bull char should result in at least some redds being constructed in areas protected from scour during large floods (i.e., risk-spreading at the subpopulation level). Females occasionally construct multiple redds within a reach (J.G. Shellberg, personal observation), which may also be a site-selection risk-spreading technique at the individual level.

\section{Frequency of disturbance}

Sediment transport and scour depths generally increased with discharge magnitude and shear stress, similar to other studies (Emmett and Leopold 1965; Carling 1987; Haschenburger 2006), with flood discharge RI and duration accounting for up to $20 \%$ of variation in scour depths. In catchments in this study, scour to cited egg burial depths did not typically commence until flood events exceeded the 2-year RI. The frequency of disturbance needed to entrain the entire bedload of these reaches and (re)create complex habitat across the channel and floodplain was greater than the 4-year RI, similar to studies on other regional rivers (e.g., Ham and Church 2000; 5-year RI). Floods larger than these observed magnitudes are needed to deposit well-sorted gravel patches below newly formed LWD jams and other obstructions to provide stable habitat during smaller floods. Even larger floods are needed to reset floodplain habitat mosaics and create side channels important for spawning refugia during common floods (e.g., Wondzell and Swanson 1999; Whited et al. 2007). Adapting the intermediate disturbance hypothesis to habitat heterogeneity rather than species diversity (Richards et al. 2002), channel-changing flood events occurring at an intermediate frequency are important in creating and maintaining complex habitat (e.g., gravel pockets near obstructions and side channels) for aquatic organisms such as bull char.

\section{Shear stress}

In addition to flood magnitude and duration, estimates of total boundary shear stress generally improved predictions of scour depth, explaining up to $60 \%$ of the variability in scour at some sites. However, other factors such as local effective (grain) shear stress and local sediment supply to specific spawning patches likely explain much of the remaining variability. Future detailed measurements of local hydraulic and velocity conditions (e.g., Wilcock 1996; Crowder and Diplas 2002) should improve local effective shear stress and scour predictions in mountain channel types.

\section{Changes in hydrology and sediment supply}

Bull char typically spawn in cold mountain valleys where catchment water, sediment, and LWD production are sensitive to proximal land surface and land use conditions (Church 2002). Building road networks and timber harvesting on potentially unstable slopes can increase the magnitude and frequency of sediment production (e.g., Beschta 
1978) and bed mobility in response to altered sediment regimes (e.g., Tripp and Poulin 1986; Madej and Ozaki 1996; Lisle et al. 2000). Changing land cover can also alter water yield (e.g., Harr et al. 1975; Bosch and Hewlett 1982; Harr 1986) and increase the magnitude of common peak flood events (i.e., <1- to 2-year RI up to the 10-year RI) in smalland medium-sized catchments (e.g., Jones and Grant 1996, 2001; Lewis et al. 2001). During this study, scour to cited egg burial depths occurred during these sensitive common peak flood events, as found in other studies (Montgomery et al. 1996; Haschenburger 2006). Changes in event magnitude and frequency could increase the frequency of disturbance of scour in char spawning areas (Tonina et al. 2008), especially if coupled with increased production of transient bed sediment and loss of instream LWD structure.

In this study, the catchments of the NF Skykomish and SF Skokomish above Church Creek remain relatively undisturbed from human activities and produce moderate to low (respectively) numbers of bull char. In contrast, the SF Skokomish River below Church Creek has been affected by the delivery of large amounts of coarse sediment (sand and gravel) from road building and timber harvesting on steep, erodible slopes, resulting in increased bed mobility. Although the upper Cedar River catchment also has been densely roaded and logged, the low-gradient pool-riffle reaches are partially decoupled (sensu Church 2002) from upstream water and sediment supply disturbances. Low stream power, gravel armor layers, and abundant gravel appear to mitigate scour depths in these pool-riffle reaches (e.g., DeVries 2000, 2002, 2008), which support high numbers of bull char. Fine sediment (clay, silt, fine sand) throughput and deposition may be a greater mortality factor in these channel types (DeVries 2008).

From these observations, we hypothesize that anthropogenically increased production of transient bed sediment to supply-limited reaches, especially sand and poorly sorted gravel, increases the frequency of spawning gravel mobility and scour to egg burial depths during relatively common flood events (i.e., 1- to 4-year RI). Bed texture and mobility are sensitive to sediment supply (Buffington and Montgomery 1999b; Lisle et al. 2000). Though large sustained influxes of gravel could force changes in channel type, anthropogenically increased bed material supplies more commonly produce episodic fluxes of poorly sorted sediment that is highly transient. In contrast, the well-sorted spawning gravels that salmonids have adapted to in mountain channels are created as gravel lag deposits in preferential deposition zones that are flushed of finer, more mobile sediment over geomorphic time scales. Thus the caliber and quantity of contemporary sediment supply and bed mobility may be good indicators of spawning habitat integrity. Other studies have noted a negative relationship between land use intensity (i.e., riparian harvest and roads disturbance) and char population abundance (Baxter et al. 1999).

\section{Loss of roughness}

Reduced LWD hydraulic roughness has been predicted to result in reach-scale bed-surface coarsening and a reduction in both the availability and retention of quality spawning substrate (Buffington and Montgomery 1999a; Buffington et al. 2004). Abundant LWD can provide spatial spawning habitat heterogeneity that salmonids actively select for and improve the redd carrying capacity of a reach (Merz 2001), in addition to reducing velocity and shear stress (this study). Bed stability has been shown to decrease following wood removal (Bilby 1984; Smith et al. 1993) and where LWD is undersized and mobile (McHenry et al. 1998; SchuettHames et al. 2000; Fox et al. 2002). A loss in the quality, quantity, and diversity of LWD roughness due to riparian logging, instream wood removal, and (or) increased hydrologic flushing may reduce the availability or quality of bull char spawning habitat (Hauer et al. 1999), especially in sediment supply limited reaches with high stream power.

\section{Implications}

This study emphasizes the importance of habitat heterogeneity and refugia availability in sustaining salmonid populations at multiple spatial scales: from catchment-scale (10$1000 \mathrm{~km}$ ) discharge regime heterogeneity and flood disturbance probability, to reach-scale (100-1000 m) channel type complexity, to local-scale $(1-10 \mathrm{~m})$ site selection and structural energy dissipation. The distribution and abundance of bull char in western Washington could have been influenced by a loss of complex fluvial spawning habitat (e.g., LWD roughness), especially in streams with limited supplies of quality gravel and harsh discharge regimes during incubation (rain or rain-on-snow dominated). Processes that form complex habitat in association with LWD (Beechie et al. 2000) may partially mitigate against unfavorable discharge regimes, water and sediment yield alterations due to landuse, or future climate change (e.g., Battin et al. 2007).

\section{Acknowledgements}

Field support for this project was provided by Carrie Furman, Jeff Bash, Ashley Adams and others, whose company and hard work are greatly appreciated. Local field advice and support by Dwayne Paige, Heidy Barnett, and Bill Belknap (Seattle Public Utilities), Mike Stutsman, Larry Ogg, and Anthony Taiber (US Forest Service), and Curt Kraemer (Washington Department of Fish and Wildlife) were essential for project success. Input from four anonymous reviewers substantially improved the manuscript, as did initial comments from Thomas Quinn and Paul DeVries. The study was funded by the US Forest Service, Pacific Northwest Research Station, and the Washington Fly Fishing Club.

\section{References}

Ames, J., and Beecher, H. 2001. Incorporating flood risk into controlled spawning flow regimes for Pacific salmon: an example using the Cedar River sockeye salmon. Washington Department of Fish and Wildlife, Olympia, Wash.

Barta, A.F., Wilcock, P.R., and Shea, C.C.C. 1994. The transport of gravels in boulder-bed streams. In Hydraulic Engineering '94. Edited by G.V. Controneo and R.R. Rumer. American Society of Civil Engineers, New York. pp. 780-784.

Bathurst, J.C., Graf, W.H., and Cao, H.H. 1983. Initiation of sediment transport in steep channels with coarse bed material. In Mechanics of Sediment Transport, Proceedings of Euromech 156 Colloquium, Istanbul, Turkey, 12-14 July 1982. Edited by B.M. Sumer and A. Muller. A.A. Balkema (Taylor and Francis), London, UK. pp. 207-213.

Battin, J., Wiley, M.W., Ruckelshaus, M.H., Palmer, R.N., Korb, 
E., Bartz, K.K., and Imaki, H. 2007. Projected impacts of climate change on salmon habitat restoration. Proc. Natl. Acad. Sci. U.S.A. 104(16): 6720-6725. doi:10.1073/pnas.0701685104. PMID: 17412830.

Baxter, C.V., Frissell, C., and Hauer, F.R. 1999. Geomorphology, logging roads, and the distribution of bull trout spawning in a forested river basin: implications for management and conservation. Trans. Am. Fish. Soc. 128(5): 854-867. doi:10.1577/15488659(1999)128<0854:GLRATD>2.0.CO;2.

Beechie, T., Pess, G., Kennard, P., Bilby, R., and Bolton, S. 2000. Modeling recovery rates and pathways for woody debris recruitment in northwestern Washington streams. N. Am. J. Fish. Manage. 20(2): 436-452. doi:10.1577/1548-8675(2000)020<0436:MRRAPF>2.3. $\mathrm{CO} ; 2$.

Beschta, R.L. 1978. Long-term patterns of sediment production following road construction and logging in the Oregon Coast Range. Water Resour. Res. 14(6): 1011-1016. doi:10.1029/ WR014i006p01011.

Bilby, R.E. 1984. Removal of woody debris may affect stream stability. J. For. 82: 609-613.

Bosch, J.M., and Hewlett, J.D. 1982. A review of catchment experiments to determine the effect of vegetation changes on water yield and evpotranspiration. J. Hydrol. (Amst.), 55(1-4): 3-23. doi:10.1016/0022-1694(82)90117-2.

Bravo-Espinosa, M., Osterkamp, W.R., and Lopes, V.L. 2003. Bedload transport in alluvial channels. J. Hydraul. Eng. 129(10): 783-795. doi:10.1061/(ASCE)0733-9429(2003)129:10(783).

Buffington, J.M., and Montgomery, D.R. 1997. A systematic analysis of eight decades of incipient motion studies, with special reference to gravel-bedded rivers. Water Resour. Res. 33: 1993-2029.

Buffington, J.M., and Montgomery, D.R. 1999a. Effects of hydraulic roughness on surface textures of gravel-bed rivers. Water Resour. Res. 35(11): 3507-3521. doi:10.1029/1999WR900138.

Buffington, J.M., and Montgomery, D.R. 1999b. Effects of sediment supply on surface textures of gravel-bed rivers. Water Resour. Res. 35(11): 3523-3530. doi:10.1029/1999WR900232.

Buffington, J.M., Montgomery, D.R., and Greenberg, H.M. 2004. Basin-scale availability of salmonid spawning gravel as influenced by channel type and hydraulic roughness in mountain catchments. Can. J. Fish. Aquat. Sci. 61(11): 2085-2096. doi:10.1139/f04-141.

Carling, P.A. 1987. Bed stability in gravel streams, with reference to stream regulation and ecology. In River channels: environment and process. Edited by K. Richards. Blackwell, Oxford, UK. pp. 321-347.

Church, M. 2002. Geomorphic thresholds in riverine landscapes. Freshw. Biol. 47(4): 541-557. doi:10.1046/j.1365-2427.2002. 00919.x.

Crowder, D.W., and Diplas, P. 2002. Vorticity and circulation: spatial metrics for evaluating flow complexity in stream habitats. Can. J. Fish. Aquat. Sci. 59(4): 633-645. doi:10.1139/f02-037.

Den Boer, P.J. 1968. Spreading of risk and stabilization of animal numbers. Acta Biotheor. 18: 163-194.

DeVries, P. 1997. Riverine salmonid egg burial depths: review of published data and implications for scour studies. Can. J. Fish. Aquat. Sci. 54(8): 1685-1698. doi:10.1139/cjfas-54-8-1685.

DeVries, P. 2000. Scour in low gradient gravel bed streams: patterns, processes, and implications for the survival of salmonid embryos. Ph.D. dissertation, University of Washington, College of Engineering, Seattle, Wash.

DeVries, P. 2002. Bedload layer thickness and disturbance depth in gravel bed streams. J. Hydraul. Eng. 128(11): 983-991. doi:10. 1061/(ASCE)0733-9429(2002)128:11(983).

DeVries, P. 2008. Bed disturbance processes and the physical me- chanisms of scour and fill in salmonid spawning habitat. In Salmon spawning habitat in rivers: physical controls, biological responses and approaches to remediation. Edited by D. Sear and P. DeVries. AFS Symp. No. 65. pp. 121-147.

Emmett, W.W., and Leopold, L.B. 1965. Downstream pattern of river-bed scour and fill. In Proceedings Federal Inter-agency Sedimentation Conference. USDA ARS Misc. Pub. No. 170. pp. 399-408.

Erman, D.C., Andrews, E.D., and Yoder-Williams, M. 1988. Effects of winter floods on fishes in the Sierra Nevada. Can. J. Fish. Aquat. Sci. 45(12): 2195-2200. doi:10.1139/f88-255.

Fox, M.J., Bolton, S., and Conquest, L. 2002. Reference conditions for instream wood in western Washington. In Restoration of Puget Sound rivers. Edited by D.R. Montgomery, S. Bolton, D. Booth, and L. Wall. University of Washington Press, Seattle, Wash. pp. 361-393.

Gibbins, C., Shellberg, J., Moir, H., and Soulsby, C. 2008. Hydrological influences on adult salmonid migration, spawning and embryo survival. In Salmon spawning habitat in rivers: physical controls, biological responses and approaches to remediation. Edited by D. Sear and P. DeVries. AFS Symp. No. 65. pp. 195-223.

Gintz, D., Hassan, M.A., and Schmidt, K.H. 1996. Frequency and magnitude of bedload transport in a mountain river. Earth Surf. Process. Landf. 21(5): 433-445. doi:10.1002/(SICI)10969837(199605)21:5<433::AID-ESP580>3.0.CO;2-P.

Goetz, F.A. 1989. Biology of bull trout, Salvelinus confluentus: a literature review. US Department of Agriculture, Forest Service, Willamette National Forest, Eugene, Oregon.

Ham, D.G., and Church, M. 2000. Bed-material transport estimated from channel morphodynamics: Chilliwack River, British Columbia. Earth Surf. Process. Landf. 25(10): 1123-1142. doi:10. 1002/1096-9837(200009)25:10<1123::AID-ESP122>3.0.CO;2-9.

Harr, R.D. 1986. Effects of clearcutting on rain-on-snow runoff in western Oregon: a new look at old studies. Water Resour. Res. 22(7): 1095-1100. doi:10.1029/WR022i007p01095.

Harr, R.D., Harper, W.C., Krieger, J.T., and Hsieh, F.S. 1975. Changes in storm hydrographs after road building and clearcutting in the Oregon Coast Range. Water Resour. Res. 11(3): 436-444. doi:10.1029/WR011i003p00436.

Haschenburger, J.K. 2006. Observations of event-based streambed deformation in a gravel bed channel. Water Resour. Res. 42(11): W11412. doi:10.1029/2006WR004985.

Hauer, F.R., Poole, G.C., Gangemi, J.T., and Baxter, C.V. 1999. Large woody debris in bull trout (Salvelinus confluentus) spawning streams of logged and wilderness watersheds in Northwest Montana. Can. J. Fish. Aquat. Sci. 56(6): 915-924. doi:10.1139/ cjfas-56-6-915.

Henderson, F.M. 1966. Open channel flow. Macmillan, New York.

Johnson, T.H. 1991. Bull trout studies in Washington, 1989. Washington Department of Wildlife, Fisheries Management Division, Port Townsend, Wash.

Jones, J.A., and Grant, G.E. 1996. Peak flow responses to clearcutting and roads in small and large basins, Western Cascades, Oregon. Water Resour. Res. 32(4): 959-974. doi:10. 1029/95WR03493.

Jones, J.A., and Grant, G.E. 2001. Comment on "Peak flow responses to clear-cutting and roads in small and large basins, Western Cascades, Oregon: a second opinion" by R.B. Thomas and W.F. Megahan. Water Resour. Res. 37(1): 175-178. doi:10. 1029/2000WR900276.

Kondolf, G.M. 1997. Application of the pebble count: notes on purpose, method and variants. J. Am. Water Resour. Assoc. 33(1): 79-87. doi:10.1111/j.1752-1688.1997.tb04084.x.

Kondolf, G.M., Cada, G.F., Sale, M.J., and Felando, T. 1991. Dis- 
tribution and stability of potential salmonid spawning gravels in steep boulder-bed streams of the eastern Sierra Nevada. Trans. Am. Fish. Soc. 120(2): 177-186. doi:10.1577/1548-8659(1991) $120<0177$ :DASOPS $>2.3 . \mathrm{CO} ; 2$.

Lapointe, M., Eaton, B., Driscoll, S., and Latulippe, C. 2000. Modeling the probability of salmonid egg pocket scour due to floods. Can. J. Fish. Aquat. Sci. 57(6): 1120-1130. doi:10.1139/cjfas57-6-1120.

Lewis, J., Mori, S.R., Keppeler, E.T., and Ziemer, R.R. 2001. Impacts of logging on storm peak flows, flow volumes and suspended sediment loads in Casper Creek, California. In Land use and watersheds: human influences on hydrology and geomorphology in urban and forest areas. Edited by M.S. Wigmosta and S.J. Burges. American Geophysical Union, Water Science and Application No. 2, Washington, D.C. pp. 85-125.

Lisle, T.E., Nelson, J.M., Pitlick, J., Madej, M.A., and Barkett, B.L. 2000. Variability of bed mobility in natural, gravel-bed channels and adjustments to sediment load at local and reach scales. Water Resour. Res. 36(12): 3743-3755. doi:10.1029/ 2000WR900238.

Lytle, D.A., and Poff, N.L. 2004. Adaptation to natural flow regimes. Trends Ecol. Evol. 19(2): 94-100. doi:10.1016/j.tree. 2003.10.002. PMID:16701235.

Madej, M.A., and Ozaki, V. 1996. Channel response to sediment wave propagation and movement, Redwood Creek, California, USA. Earth Surf. Process. Landf. 21(10): 911-927. doi:10.1002/ (SICI)1096-9837(199610)21:10<911::AID-ESP621>3.0.CO;2-1.

McHenry, M.L., Shott, E., Conrad, R.H., and Grette, G.B. 1998. Changes in the quantity and characteristics of large woody debris in streams of the Olympic Peninsula, Washington, U.S.A. (1982-1993). Can. J. Fish. Aquat. Sci. 55(6): 1395-1407. doi:10.1139/cjfas-55-6-1395.

McPhail, J.D., and Murray, C. 1979. The early life history and ecology of Dolly Varden (Salvelinus malma) in the Upper Arrow Lakes. Report to B.C. Hydro Power Authority and Kootenay Department of Fish and Wildlife, Vancouver, B.C., by the Department of Zoology, University of British Columbia.

Merz, J.E. 2001. Association of fall-run chinook salmon redds with woody debris in the lower Mokelumne River, California. Calif. Fish Game, 87: 51-60.

Montgomery, D.R., and Buffington, J.M. 1997. Channel-reach morphology in mountain drainage basins. Geol. Soc. Am. Bull. 109(5): 596-611. doi:10.1130/0016-7606(1997)109<0596:CRMIMD>2.3. $\mathrm{CO} ; 2$.

Montgomery, D.R., Buffington, J.M., Peterson, N.P., SchuettHames, D., and Quinn, T.P. 1996. Stream-bed scour, egg burial depths, and the influence of salmonid spawning on bed surface mobility and embryo survival. Can. J. Fish. Aquat. Sci. 53(5): 1061-1070. doi:10.1139/cjfas-53-5-1061.

Montgomery, D.R., Beamer, E.M., Pess, G., and Quinn, T.P. 1999. Channel type and salmonid distribution and abundance. Can. J. Fish. Aquat. Sci. 56: 377-387. doi:10.1139/cjfas-56-3-377.

Rantz, S.E. 1982. Measurement and computation of streamflow. US Geol. Surv. Water Supply Paper No. 2175, Washington, D.C.

Rennie, C.D., and Millar, R.G. 2000. Spatial variability of stream bed scour and fill: a comparison of scour depth in chum salmon (Oncorhynchus keta) redds and adjacent bed. Can. J. Fish. Aquat. Sci. 57(5): 928-938. doi:10.1139/cjfas-57-5-928.

Richards, K., Brasington, J., and Hughes, F. 2002. Geomorphic dynamics of floodplains: ecological implications and a potential modelling strategy. Freshw. Biol. 47(4): 559-579. doi:10.1046/j. 1365-2427.2002.00920.x.

Schuett-Hames, D., Conrad, R., Pleus, A.E., and Lautz, K. 1999.
Salmonid spawning gravel scour survey. NW Indian Fisheries Commission, Timber Fish and Wildlife Report No. TFW-AM999-008, Olympia, Wash.

Schuett-Hames, D.E., Peterson, N.P., Conrad, R., and Quinn, T.P. 2000. Patterns of gravel scour and fill after spawning by chum salmon in a western Washington stream. N. Am. J. Fish. Manage. 20(3): 610 617. doi:10.1577/1548-8675(2000)020<0610:POGSAF>2.3.CO;2.

Sedell, J.R., Reeves, G.H., Hauer, F.R., Stanford, J.A., and Hawkins, C.P. 1990. Role of refugia in recovery from disturbances: modern fragmented and disconnected river systems. Environ. Manage. 14(5): 711-724. doi:10.1007/BF02394720.

Seegrist, D.W., and Gard, R. 1972. Effects of floods on trout in Sagehen Creek, California. Trans. Am. Fish. Soc. 101(3): 478-482. doi:10.1577/1548-8659(1972)101<478:EOFOTI>2.0.CO;2.

Shellberg, J.G. 2002. Hydrologic, geomorphic, and biologic influences on redd scour in bull char (Salvelinus confluentus) spawning streams. M.S. thesis, University of Washington, College of Forest Resources, Seattle, Wash.

Shepard, B.B., Pratt, K., and Graham, P.J. 1984. The life histories of westslope cutthroat and bull trout in the upper Flathead River Basin, Montana. Montana Department of Fish, Wildlife and Parks, Kalispell, Montana.

Smith, R.D., Sidle, R.C., and Porter, P.E. 1993. Effects on bedload transport of experimental removal of woody debris from a forest gravel-bed stream. Earth Surf. Process. Landf. 18(5): 455-468. doi:10.1002/esp.3290180507.

Stutsman, M.R., and Ogg, L.W. 2002. Summary report of the Olympic National Forest Bull Trout Recovery Project 19952001. USDA Forest Service, Olympic National Forest, Hoodsport, Wash.

Sumioka, S.S., Kresch, D.L., and Kasnick, K.D. 1998. Magnitude and flood frequency in Washington. US Geological Survey, Water Resources Investigations Report No. 97-4277, Tacoma, Wash.

Tonina, D., Luce, C.H., Rieman, B., Buffington, J.M., Goodwin, P., Clayton, S.R., Ali, S.M., Barry, J.J., and Berenbrock, C. 2008. Hydrological response to timber harvest in northern Idaho: implications for channel scour and persistence of salmonids. Hydrol. Process. 22(17): 3223-3235. doi:10.1002/hyp.6918.

Tripp, D.B., and Poulin, V.A. 1986. The effects of logging and mass wasting on salmonid spawning habitat in streams on the Queen Charlotte Islands. B.C. Ministry of Forest Lands, Land Management Report No. 50, Vancouver, B.C., Canada.

US Fish and Wildlife Service. 1998. Bull trout interim conservation guidance. US Fish and Wildlife Service (USFWS), Lacey, Wash.

Whited, D.C., Lorang, M.S., Harner, M.J., Hauer, F.R., Kimball, J.S., and Stanford, J.A. 2007. Climate, hydrologic disturbance, and succession: drivers of floodplain pattern. Ecology, 88(4): 940-953. doi:10.1890/05-1149. PMID:17536710.

Wilcock, P.R. 1996. Estimating local bed shear stress from velocity observations. Water Resour. Res. 32(11): 3361-3366. doi:10. 1029/96WR02277.

Wondzell, S.M., and Swanson, F.J. 1999. Floods, channel change, and the hyporheic zone. Water Resour. Res. 35(2): 555-567. doi:10.1029/1998WR900047.

Zar, J.H. 1999. Biostatistical analysis. 4th ed. Prentice Hall, Upper Saddle River, New Jersey.

Zimmermann, A., and Church, M. 2001. Channel morphology, gradient profiles and bed stresses during flood in a step-pool channel. Geomorphology, 40(3-4): 311-327. doi:10.1016/S0169555X(01)00057-5. 